\title{
Physical properties of buckwheat (Fagopyrum esculentum Moench) grains during convective drying
}

\author{
Wellytton D. Quequeto ${ }^{1}$, Valdiney C. Siqueira ${ }^{2}$, Vanderleia Schoeninger ${ }^{2}$, \\ Elton A. S. Martins ${ }^{2}$, Eder P. Isquierdo ${ }^{3} \&$ Fernanda P. da Silva ${ }^{2}$ \\ ${ }^{1}$ Instituto Federal Goiano/Campus Rio Verde. Rio Verde, GO. E-mail: wellytton_quequeto@hotmail.com (Corresponding author) - ORCID: 0000-0002- \\ 0658-2692 \\ ${ }^{2}$ Universidade Federal da Grande Dourados/Faculdade de Ciências Agrárias. Dourados, MS. E-mail: vcambuy@yahoo.com - ORCID: 0000-0003-3698-0330; \\ vschoeninger@ufgd.edu.br - ORCID: 0000-0001-7308-4709; eltonmartins@ufgd.edu.br - ORCID: 0000-0002-3195-2317; fehpimentel@hotmail.com - ORCID: \\ 0000-0002-6202-3043 \\ ${ }^{3}$ Universidade do Estado de Mato Grosso/Campus de Cáceres. Cáceres, MT. E-mail: eder.isquierdo@yahoo.com.br - ORCID: 0000-0002-3715-0999
}

\section{Key words:}

post-harvest moisture content volumetric shrinkage

\begin{abstract}
A B S T R A C T
Buckwheat is a prominent crop in present-day agriculture due to its nutraceutical properties; however, information on this crop regarding the post-harvest process is scarce, as well as the characterization of its physical properties and such information is essential for the development and improvement of machinery used in post-harvest processes. Thus, the objective of this study was to determine the volumetric shrinkage, porosity, bulk density and true density of buckwheat grains throughout the drying process, as well as to fit mathematical models to the experimental values of true and bulk volumetric shrinkages. Buckwheat grains of the cultivar IPR 91 - Baili with an initial moisture content of 0.250 (decimal, dry basis.) were used. The samples used to determine the physical properties were subjected to oven drying with forced air circulation stabilized at $40 \pm 1^{\circ} \mathrm{C}$. The mass of the samples was periodically weighed, so that when the product reached predetermined values of moisture content, the samples were removed and their physical properties were determined. It is concluded that the reduction in moisture content during drying causes increase in bulk density, true density and porosity. The reduction of the moisture content influences bulk volumetric shrinkage and true volumetric shrinkage of the grains, causing reductions in their values of approximately 14.47 and $14.70 \%$, respectively, and a linear model can represent both variables satisfactorily.
\end{abstract}

\section{Palavras-chave:}

pós-colheita teor de água contração volumétrica

\section{Propriedades físicas de grãos de trigo mourisco (Fagopyrum esculentum Moench) durante a secagem convectiva}

\section{R E S U M O}

O trigo mourisco é uma cultura de destaque na agricultura atual devido às suas propriedades nutracêuticas; no entanto, informações dessa cultura referente ao processo pós-colheita são escassas, assim como a caracterização de suas propriedades físicas, sendo que tais informações são essenciais para o desenvolvimento e aperfeiçoamento de maquinários utilizados nos processos pós-colheita. Deste modo, objetivou-se com o presente trabalho determinar a contração volumétrica, a porosidade, as massas específicas aparente e unitária dos grãos de trigo mourisco ao longo do processo de secagem, bem como ajustar modelos matemáticos aos valores experimentais da contração unitária e da massa. Foram utilizados grãos de trigo mourisco da cultivar IPR 91 - Baili, com teor de água inicial de 0,250 (decimal, base seca). As amostras utilizadas para determinação das propriedades físicas foram submetidas à secagem em estufa com circulação forçada de ar estabilizada à temperatura de $40 \pm 1^{\circ} \mathrm{C}$. A massa das amostras foi pesada periodicamente, de modo que, quando o produto atingisse valores pré-estabelecidos de teor de água, eram retiradas e encaminhadas para determinação de suas propriedades físicas. Conclui-se que, a redução do teor de água durante a secagem causa o aumento da massa específica aparente e unitária e da porosidade. A redução do teor de água influencia a contração volumétrica da massa e contração volumétrica unitária dos grãos, provocando redução em seus valores de aproximadamente 14,47 e $14,70 \%$, respectivamente, em que ambas as variáveis podem ser representadas satisfatoriamente por um modelo linear. 


\section{INTRODUCTION}

Buckwheat (Fagopyrum esculentum Moench) is a dicotyledonous plant belonging to the Polygonaceae family, with no kinship with common wheat. Its flour does not contain gluten and is mainly recommended for people with celiac disease; in addition, it positively affects human organism (Wronkowska et al., 2010).

Buckwheat protein is of excellent quality and has high content of lysine, an essential amino acid which is deficient in most common cereals (Rodrigues \& Oliveira, 2010). It contains dietary fiber, resistant starch, rutin and mineral salts, besides a high level of essential polyunsaturated fatty acids and several vitamins (Sedej et al., 2011).

Given the economic potential, up to present time some studies have been conducted with the crop, related to yield (Görgen et al., 2016), adaptation (Alves et al., 2016), cultivation (Vazhov et al., 2013) and nutritional properties (Zhu, 2016). However, information on drying and physical properties of this species is very vague. Variations in true density, bulk density, porosity and volumetric shrinkage are observed in several agricultural products along the drying process (Payman et al., 2011; Mir et al., 2013; Botelho et al., 2016; Smaniotto et al., 2016; Sousa et al., 2016). These properties are of extreme importance to optimize the post-harvest process because they are necessary in the calculations of the static capacity of the silo, dimensioning of dryers, transporters and fans for drying and aeration systems.

Given the lack of information on the physical properties of buckwheat during drying, the present work aimed to determine the volumetric shrinkage, porosity, bulk density and true density of buckwheat grains along the drying process, as well as to fit mathematical models to the experimental values of true and bulk volumetric shrinkage.

\section{Material AND Methods}

The study was conducted at the Laboratory of Physical Properties of Agricultural Products of the Faculty of Agrarian Sciences, belonging to the Federal University of Grande Dourados, located in the municipality of Dourados, MS, Brazil.

Grains of the buckwheat cultivar IPR 91 - Baili, mechanically harvested, with initial moisture content of 0.250 (decimal, d.b.) were used in the experiment.

The initial moisture content of the samples was determined using the oven method described by the Rules for Seed Analysis (Brasil, 2009), modified, using a forced ventilation oven at 105 $\pm 1{ }^{\circ} \mathrm{C}$ for $24 \mathrm{~h}$, in three replicates.

The buckwheat samples used to determine physical properties were subjected to drying in forced air circulation oven stabilized at temperature of $40 \pm 1{ }^{\circ} \mathrm{C}$, providing relative humidity of $22 \pm 2.3 \%$, and this value was obtained by basic principles of psychrometry.

Drying was monitored based on mass difference, by knowing the initial moisture content of the product. As drying began, the mass of the samples was weighed periodically on a semi-analytical scale with $0.01 \mathrm{~g}$ resolution. When the product reached preestablished moisture contents $(0.250,0.234,0.219$,
$0.204,0.190,0.176,0.162,0.149$ and 0.136 , decimal d.b.), the samples were removed and their physical properties were determined.

The true density of the grain mass $\left(\rho_{t}\right)$ was determined by the direct method, with addition of hexane, in a known mass of grains. This solvent was used because it has low density and is not absorbed by the grains (Donadon et al., 2012). All tests were conducted using a $30-\mathrm{mL}$ flask and a $50-\mathrm{mL}$ burette. By knowing the mass of the grains, mass and volume of the flask and solvent density, it was possible to obtain the total volume of the sample, which was divided by the number of grains to determine the individual volume.

Bulk density $\left(\rho_{\mathrm{b}}\right)$, in $\mathrm{kg} \mathrm{m}^{-3}$, for the product was determined using a scale of hectoliter weight, with $1 \mathrm{~L}$ volume, with three replicates for each moisture content, as described by Siqueira et al. (2012a).

Porosity $(\varepsilon$, in \%) of buckwheat seeds was indirectly calculated by Eq. 1 (Mohsenin, 1986), traditionally used for agricultural products.

$$
\varepsilon=\left(1-\frac{\rho b}{\rho t}\right) \times 100
$$

The experimental data relative to the bulk density, true density and porosity of buckwheat grains were subjected to linear regression analysis. Regression models were fitted using the computer program SigmaPlot 11.0 (Systat Software Inc., 2008). The criteria to select the models were their significance level by $\mathrm{F}$ test, along with the coefficients of determination $\left(\mathrm{R}^{2}\right)$.

To determine the coefficients of true and bulk volumetric shrinkages of buckwheat grains, the ratio between the product volume at a certain instant and its initial volume was calculated using Eq. 2 (Siqueira et al., 2012b).

$$
\Psi=\frac{\mathrm{V}}{\mathrm{V}_{0}}
$$

where:

$\Psi$ - coefficient of volumetric shrinkage, dimensionless;

$\mathrm{V}$ - volume (of the mass or grain) at a certain instant, $\mathrm{cm}^{3}$; and,

$\mathrm{V}_{0}$ - initial volume (of the mass or grain), $\mathrm{cm}^{3}$.

Bulk volumetric shrinkage was monitored based on an initial volume of $150 \mathrm{~cm}^{3}(150 \mathrm{~mL})$ of buckwheat grains. The reduction of this volume was verified along the drying process by transferring the grain mass to a $150-\mathrm{cm}^{3}$ cylinder and recording the volume for the predetermined moisture contents during the drying. For each moisture content sampled, three measurements of grain mass volume were taken in the $150-\mathrm{cm}^{3}$ cylinder, and the grain mass volume was represented by the mean of these three measurements.

Mathematical models (Table 1) were fitted to the experimental data of coefficients of true and bulk volumetric shrinkage of buckwheat grains.

The experimental data of true volumetric shrinkage and bulk volumetric shrinkage were subjected to nonlinear regression analysis by the Gauss-Newton method. The models 
Table 1. Mathematical models used to represent the coefficients of true and bulk volumetric shrinkage of buckwheat grains as a function of moisture content

\begin{tabular}{|c|c|c|}
\hline Model designation & Model & \\
\hline Rahman (1995) & $\Psi=1+\beta\left(U-U_{0}\right)$ & (3) \\
\hline Corrêa et al. (2004) & $\Psi=1 /[a+b \exp (U)]$ & (4) \\
\hline Exponential & $\Psi=\mathrm{a} \exp (\mathrm{b} U)$ & (5) \\
\hline Linear & $\Psi=a+b U$ & (6) \\
\hline $2^{\text {nd }}$ order polynomial & $\Psi=a+b U+c U^{2}$ & (7) \\
\hline Modified Bala \& Woods (1984) & $\Psi=1-a\left\{1-\exp \left[-b\left(U_{0}-U\right)\right]\right\}$ & (8) \\
\hline
\end{tabular}

Where: $U$ - Moisture content of the product, decimal d.b.; $U_{0}$ - Initial moisture content of the product, decimal d.b.; a, b, c - Parameters depending on the product, dimensionless; $\beta$ - Volumetric shrinkage coefficient, dimensionless

were fitted to the experimental data using the computer program Statistica 7.0 (Statistica, 2005).

The models to represent the volumetric shrinkage coefficient were selected considering the values of the relative mean error $(\mathrm{P})$, standard error of the estimate (SE), coefficient of determination $\left(\mathrm{R}^{2}\right)$ and residual distribution. Relative mean error and standard error of the estimate were calculated according to Eqs. 9 and 10 (Siqueira et al., 2012b):

$$
\begin{aligned}
& \mathrm{P}=\frac{100}{\mathrm{n}} \sum_{\mathrm{i}=1}^{\mathrm{n}}\left(\frac{|\mathrm{Y}-\hat{\mathrm{Y}}|}{\mathrm{Y}}\right) \\
& \mathrm{SE}=\sqrt{\frac{\sum_{\mathrm{i}=1}^{\mathrm{n}}(\mathrm{Y}-\hat{\mathrm{Y}})^{2}}{\mathrm{DF}}}
\end{aligned}
$$

where:

$$
\begin{array}{ll}
\mathrm{n} & \text { - number of experimental observations; } \\
\mathrm{Y} & \text { - experimental value; } \\
\hat{Y} & \text { - value estimated by the model; and, } \\
\mathrm{DF} & \text { - degrees of freedom of the model. }
\end{array}
$$

\section{Results AND Discussion}

Bulk density and true density of buckwheat grains increased with the reduction in moisture content (Figure 1). The estimated values of bulk density and true density of buckwheat grains varied from 633.24 to $663.91 \mathrm{~kg} \mathrm{~m}^{-3}$ and from 1089.28 to $1252.17 \mathrm{~kg} \mathrm{~m}^{-3}$, respectively, for a variation in product moisture content from 0.250 to 0.136 (decimal, d.b.). Such behavior is similar to those of most agricultural products studied (Firouzi et al., 2009; Payman et al., 2011; Oliveira Neto et al., 2012; Jesus et al., 2013; Theertha et al., 2014).

With the reduction in moisture content and consequently in the volume, the grains were more easily arranged within the container, increasing the bulk density, as described by Siqueira et al. (2012a). True density tends to increase because the densities of the main compounds of the grain (carbohydrates and proteins) are higher than the density of water (USDA, 1975), which was removed by the drying process.

It was also observed in Figure 1 ( A and B) that the variation in bulk density and true density as a function of the reduction in moisture content can be satisfactorily represented by linear models, which indicates that, with the drying, the densities
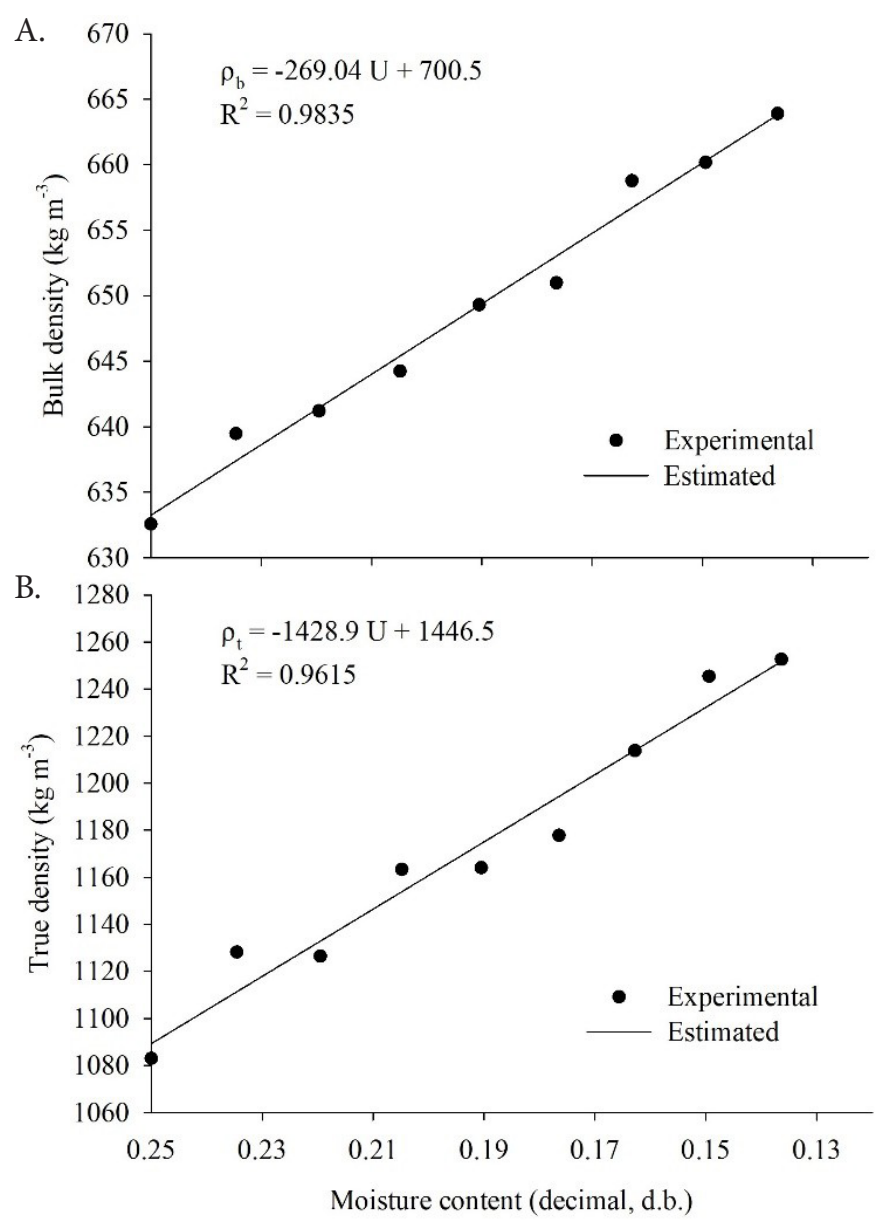

Figure 1. Experimental and estimated values of bulk density $\left(\rho_{\mathrm{b}}\right)(\mathrm{A})$ and true density $\left(\rho_{\mathrm{t}}\right)(\mathrm{B})$ of buckwheat grains as a function of moisture content $(U)$

increased proportionally, as observed by other researchers (Solomon \& Zewdu, 2009; Sousa et al, 2016).

Porosity values increased as moisture content decreased (Figure 2). Kingsly et al. (2006) and Kibar \& Öztürk (2008) reported a similar increment in the voids of the grain masses of pomegranate and soybean, respectively. This behavior is probably associated with the pyramid shape of the product

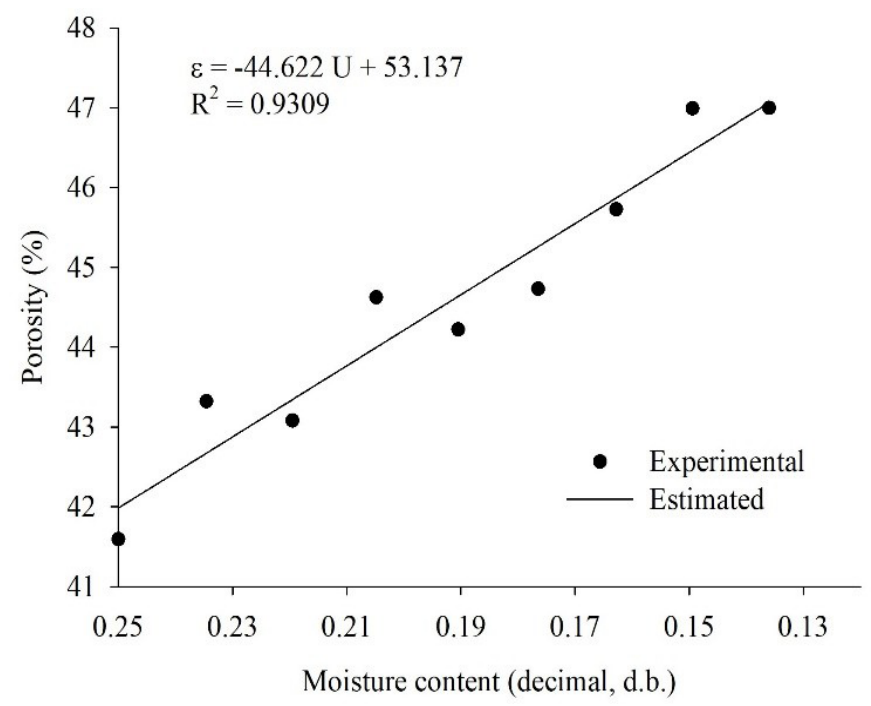

Figure 2. Experimental and estimated values of porosity $(\varepsilon)$ in the mass of buckwheat grains as a function of moisture content (U) 
(Oliveira et al., 2015). The linear model satisfactorily represents the experimental values, showing high coefficient of determination $\left(\mathrm{R}^{2}\right)$. Porosity in the mass of buckwheat grains had estimated values between 41.98 and $47.06 \%$ within the studied range of moisture content. Thus, it was found that, in air movement systems, the lower the moisture content, the lower the resistance offered by the grain mass to the passing of the air, since there is formation of more voids.

Table 2 shows the regression equations for bulk volumetric shrinkage and true volumetric shrinkage of buckwheat grains as a function of moisture content, with their respective coefficients of determination, relative mean error, standard error of the estimate, and residual distribution. All models fitted had low values of relative mean error, all below 10 . According to Mohapatra \& Rao (2005), the relative mean error is a parameter that can be used to recommend or not a model. Relative mean error values reflect the deviation of the observed values with respect to the curve estimated by the model (Kashaninejad et al., 2007). Thus, in this case, the deviation can be considered as acceptable.

The standard error of the estimate (SE) demonstrates the capacity of a model to accurately describe a certain physical process, and the lower its value, the better the quality of fit of the model in comparison to the experimental data (Siqueira et al., 2012b). Thus, all models used showed a good fit, for bulk volumetric shrinkage and true volumetric shrinkage, since their values are very low.

The good behavior of the models in comparison to the experimental data can also be observed in the residual distribution, which was random in all cases, indicating good fit (Goneli et al., 2011), and in the coefficients of determination, which were above 0.95 for all conditions. Madamba et al. (1996) claim that it indicates satisfactory representation by the models used.

Based on a joint analysis of the statistical parameters, it is possible to state that all models used to represent bulk volumetric shrinkage and true volumetric shrinkage of buckwheat grains can be recommended with high reliability,

Table 2. Models of bulk volumetric shrinkage and true volumetric shrinkage of buckwheat grains with their respective coefficients of determination $\left(R^{2}\right.$, decimal), standard error of the estimate (SE, decimal), relative mean error $(\mathrm{P}, \%)$, and residual distribution

\begin{tabular}{ccccc}
\hline Models & $\mathbf{P}$ & $\mathbf{S E}$ & $\mathbf{R}^{2}$ & Residual \\
\hline 3 & 0.4999 & 0.0062 & 0.9863 & $\mathrm{R}$ \\
4 & 0.4550 & 0.0057 & 0.9940 & $\mathrm{R}$ \\
5 & 0.5011 & 0.0062 & 0.9931 & $\mathrm{R}$ \\
6 & 0.4660 & 0.0057 & 0.9941 & $\mathrm{R}$ \\
7 & 0.4860 & 0.0058 & 0.9939 & $\mathrm{R}$ \\
8 & 0.4418 & 0.0059 & 0.9875 & $\mathrm{R}$ \\
\hline \multicolumn{5}{c}{ True } \\
3 & 0.8725 & 0.0116 & 0.9546 & $\mathrm{R}$ \\
4 & 0.9282 & 0.0119 & 0.9758 & $\mathrm{R}$ \\
5 & 0.8414 & 0.0106 & 0.9810 & $\mathrm{R}$ \\
6 & 0.8183 & 0.0100 & 0.9832 & $\mathrm{R}$ \\
7 & 0.7217 & 0.0095 & 0.9870 & $\mathrm{R}$ \\
8 & 0.8725 & 0.0116 & 0.9546 & $\mathrm{R}$ \\
\hline
\end{tabular}

R-Random since all models evaluated showed low SE values, $P$ values below $10 \%$ and $\mathrm{R}^{2}$ values above $95 \%$ (Draper \& Smith, 1998; Goneli et al., 2011; Siqueira et al., 2012b).

Among all models fitted to the experimental data, the linear model is the simplest one and was therefore used to describe the phenomenon of shrinkage. In addition, it has been recommended to represent the volumetric shrinkage of other agricultural products, such as soybean (Smaniotto et al., 2016), common beans (Oliveira Neto et al., 2012) and peanut (Payman et al., 2011). The excellent fit of the model, reliably representing the behavior of bulk and true volumetric shrinkage of buckwheat grains, can be seen in Figure 3.

According to the results, the estimated values of the mass of buckwheat grains showed a reduction in the initial volume of about $14.47 \%$ and in the true volumetric shrinkage, following the same behavior, was $14.70 \%$ for the moisture content range from 0.250 to 0.136 (decimal, d.b.). If the linear model is adopted to represent the shrinkage, for every 0.01 variation (decimal, d.b.) in the moisture content, there was a $0.0128 \%$ variation in the true volumetric shrinkage. For bulk volumetric shrinkage, there was a variation of $0.0129 \%$. These data are of extreme importance to optimize the use of dryers, because they can be used to calculate the volume necessary to refill the dryer's drying chamber, so that it works always full, ensuring maximum productivity.
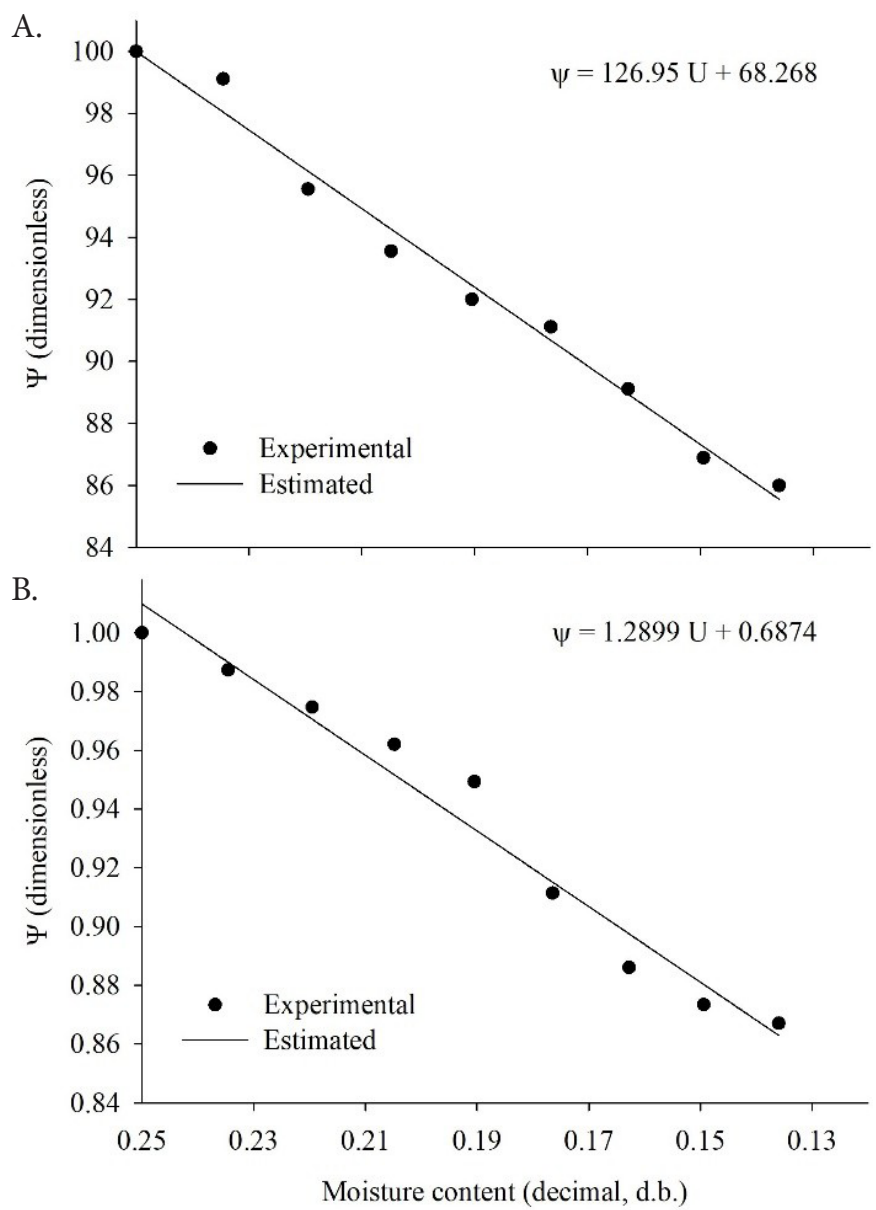

Figure 3. Coefficients of bulk volumetric shrinkage (A) and true volumetric shrinkage (B) of buckwheat grains, experimental and estimated by the linear model as a function of moisture content 


\section{Conclusions}

1. Reduction in moisture content during drying causes increase in bulk density, true density and porosity.

2. Reduction in moisture content influences bulk volumetric shrinkage and true volumetric shrinkage of buckwheat grains, causing reductions in their values of approximately 14.47 and $14.70 \%$, respectively, and both variables can be satisfactorily represented by the linear model of shrinkage.

\section{Literature Cited}

Alves, J. D. C.; Souza, A. P. D.; Pôrto, M. L.; Fontes, R. L.; Arruda, J.; Marques, L. F. Potential of sunflower, castor bean, common buckwheat and vetiver as lead phytoaccumulators. Revista Brasileira de Engenharia Agrícola e Ambiental, v.20, p.243249, 2016. https://doi.org/10.1590/1807-1929/agriambi. v20n3p243-249

Bala, B. K.; Woods, J. L. Simulation of deep bed malt drying. Journal Agricultural Engineering Research, v.30, p.235-244, 1984. https:// doi.org/10.1016/S0021-8634(84)80024-4

Botelho, F. M.; Corrêa, P. C.; Botelho, S. D. C. C.; Elías, G. A. V.; Almeida, M. D. S. D.; Oliveira, G. H. H. Propriedades físicas de frutos de café robusta durante a secagem: Determinação e modelagem. Coffee Science, v.11, p.65-75, 2016.

Brasil. Ministério da Agricultura, Pecuária e Abastecimento. Regras para análise de sementes. Brasília: MAPA, 2009.395p.

Corrêa, P. C.; Ribeiro, D. M.; Resende, O.; Afonso Júnior, P. C.; Goneli, A. L. D. Mathematical modelling for representation of coffee berry volumetric shrinkage. In: International Drying Symposium, 14, 2004, São Paulo. Proceedings... São Paulo: IDS, 2004. p.742-747.

Donadon, J. R.; Resende, O.; Castro, C. F. S.; Mendes, U. C.; Gonçalves, D. N. Comparação entre o tolueno e o hexano na determinação da porosidade intergranular de diferentes produtos agrícolas. Revista Brasileira de Armazenamento, v.37, p.37-40, 2012.

Draper, N. R.; Smith, H. Applied regression analysis. 3.ed. New York: Wiley, 1998. 736p.

Firouzi, S.; Vishgaei, M. N. S.; Kaviani, B. Some physical properties of groundnut (Arachis hypogaea L.) kernel cv. NC2 as a function of moisture content. American-Eurasian Journal of Agricultural \& Environmental Sciences, v.6, p.675-679, 2009.

Goneli, A. L. D.; Corrêa, P. C.; Magalhães, F. E. de A.; Baptestini, F. M. Contração volumétrica e forma dos frutos de mamona durante a secagem. Acta Scientiarum. Agronomy, v.33, p.1-8, 2011. https:// doi.org/10.4025/actasciagron.v33i1.4629

Görgen, A. V.; Cabral Filho, S. L. S.; Leite, G. G.; Spehar, C. R.; Diogo, J. M. S.; Ferreira, D. B. Produtividade e qualidade da forragem de trigo-mourisco (Fagopyrum esculentum Moench) e de milheto (Pennisetum glaucum (L.) R.BR). Revista Brasileira de Saúde e Produção Animal, v.17, p.599-607, 2016. https://doi.org/10.1590/ s1519-99402016000400004

Jesus, F. F.; Souza, R. T. G.; Teixeira, G. C. S.; Teixeira, I. R.; Devilla, I. A. Propriedades físicas de sementes de feijão em função de teores de água. Engenharia na Agricultura, v.21, p.09-18, 2013.

Kashaninejad, M.; Mortazavi, A.; Safekordi, A.; Tabil, L. G. Thin-Iayer drying characteristics and modeling of pistachio nuts. Journal of Food Engineering, v.78, p.98-108, 2007. https://doi.org/10.1016/j. jfoodeng.2005.09.007
Kibar, H.; Öztürk, T. Physical and mechanical properties of soybean. International Agrophysics, v.22, p.239-244. 2008.

Kingsly, A. R. P.; Singh, D. B.; Manikantan, M. R.; Jain, R. K. Moisture dependent physical properties of dried pomegranate seeds (Anardana). Journal of Food Engineering, v.75, p.492-496, 2006. https://doi.org/10.1016/j.jfoodeng.2005.04.033

Madamba, P. S.; Driscoll, R. H.; Buckle, K. A. The thin layer drying characteristic of garlic slices. Journal of Food Engineering, v.29, p.75-97, 1996. https://doi.org/10.1016/0260-8774(95)00062-3

Mir, S. A.; Bosco, S. J. D.; Sunooj, K. V. Evaluation of physical properties of rice cultivars grown in the temperate region of India. International Food Research Journal, v.20, p.1521-1527, 2013.

Mohapatra, D.; Rao, P. S. A thin layer drying model of parboiled wheat. Journal of Food Engineering, v.66, p.513-518, 2005. https://doi. org/10.1016/j.jfoodeng.2004.04.023

Mohsenin, N. N. Physical properties of plant and animal materials. New York: Gordon and Breach Publishers, 1986. 841p.

Oliveira, F. de; Ritto, J. L. A.; Jorge, L. I. F.; Barroso, I. C. E.; Prado, B. W. Microscopia de alimentos: Exames microscópicos de alimentos in natura e tecnologicamente processado. Rio de Janeiro: Editora Atheneu, 2015. 412p.

Oliveira Neto, M. C. de; Reis, R. C.; Devilla, I. A. Propriedades físicas de sementes de feijão (Phaseolus vulgaris L.) variedade "Emgopa 201-Ouro". Revista Agrotecnologia, v.1, p.99-110, 2012. https:// doi.org/10.12971/2179-5959.v01n01a07

Payman, S. H.; Ajdadi, F. R.; Bagheri, I.; Alizadeh, M. R. Effect of moisture content on some engineering properties of peanut varieties. Journal of Food, Agriculture \& Environment, v.9, p.326-331, 2011.

Rahman, S. Physical properties of foods. Boca Raton: CRC Press LLC, 1995. 500p.

Rodrigues, C. M.; Oliveira, V. R. Utilização de farinha de trigo sarraceno em associação com farinha de arroz e soja na elaboração de minipizzas. Alimentos e Nutrição, v.21, p.21-24, 2010.

Sedej, I.; Sakač, M.; Mandić, A.; Mišan, A.; Pestorić, M.; Šimurina, O.; Čanadanović-Brunet, J. Quality assessment of gluten-free crackers based on buckwheat flour. Food Science and Technology, v.44, p.694-699, 2011. https://doi.org/10.1016/j.lwt.2010.11.010

Siqueira, V. C.; Resende, O.; Chaves, T. H. Propriedades físicas dos frutos de pinhão-manso durante a secagem. Global Science and Technology, v.5, p.83-92, 2012a. https://doi.org/10.14688/19843801/gst.v5n1p83-92

Siqueira, V. C.; Resende, O.; Chaves, T. H. Determination of the volumetric shrinkage in jatropha seeds during drying. Acta Scientiarum. Agronomy. v.34, p.231-238, 2012b. https://doi. org/10.4025/actasciagron.v34i3.14402

Smaniotto, T. A. de S.; Resende, O.; Oliveira, D. E. C. de; Siqueira, V. C.; Sousa, K. A. Ajuste de modelos matemáticos a contração volumétrica unitária e da massa dos grãos de soja. Revista Agro@mbiente On-line, v.9, p.397-404, 2016.

Solomon, W. K.; Zewdu, A. D. Moisture-dependent physical properties of niger (Guizotia abyssinica Cass.) seed. Industrial Crops and Products, v.29, p.165-170, 2009. https://doi.org/10.1016/j. indcrop.2008.04.018

Sousa, R. V. de; Mata, M. E. R. C.; Duarte, M. E. M.; Almeida, R. D.; Rosa, M. E. C.; Sousa, A. C. de. Influência do teor de água nas propriedades físicas dos grãos de arroz vermelho em casca. Revista Brasileira de Produtos Agroindustriais, v.18, p.495-502, 2016. https://doi.org/10.15871/1517-8595/rbpa.v18nespp495-502 
Statistica. Statistica 7.0. EUA Software. Tulsa: StatSof, 2005.

Systat Software Inc. SigmaPlot for windows, trial version 14.0. 2016. Available on: <http://www.systat.com>. Access on: Aug. 2017.

Theertha, D. P.; Sujeetha, J. A. R. P.; Abirami, C. V. K.; Alagusundaram, K. Effect of moisture content on physical and gravimetric properties of black gram (Vigna mungo L.). International Journal of Advancements in Research \& Technology, v.3, p.97104, 2014.

USDA - United States Department of Agriculture. Handbook of the nutritional contents of foods. New York: Dove Publications, 1975. 190p.
Vazhov, V. M.; Kozil, V. N.; Odintsev, A. V. General methods of buckwheat cultivation in Altai region. World Applied Sciences Journal, v.9, p.1157-1162 2013.

Wronkowska, M.; Zielińska, D.; Szawara-Nowak, D.; Troszyńska, A.; SoralŚmietana, M. Antioxidative and reducing capacity, macroelements content and sensorial properties of buckwheat enhanced gluten free bread. International Journal of Food Science \& Technology, v.45, p.1993-2000, 2010. https://doi.org/10.1111/j.1365-2621.2010.02375.x Zhu, F. Chemical composition and health effects of Tartary buckwheat. Food Chemistry, v.203, p.231-245, 2016. https://doi.org/10.1016/j. foodchem.2016.02.050 